Jurnal Kesehatan Karya Husada, Vol 8 No 2 Tahun 2020

PISSN 2337649X/EISSN 2655-8874

Siti Maryati “"Perilaku pijat Bayi Efektif dalam Meningkatkan Pengetahuan dan Keterampilan Kader Balita di Puskesmas Pajangan Bantul" (hal 132-147)

Received

06 Juni 2020
Revisied

28 Juli 2020
Acceptep

15 Oktober 2020

\title{
PELATIHAN PIJAT BAYI EFEKTIF DALAM MENINGKATKAN PENGETAHUAN DAN KETERAMPILAN KADER BALITA DI PUSKESMAS PAJANGAN BANTUL
}

\author{
Siti Maryati ${ }^{1}$ \\ ${ }^{1}$ Prodi Diploma Tiga Keperawatan Politeknik Kesehatan Karya Husada Yogyakarta \\ Email : maryatisiti52@gmail.com
}

\begin{abstract}
ABSTRAK
Pijat bayi merupakan terapi sentuh yang telah ada sejak zaman dulu. Pijat ini memberikan manfaat yang begitu besar apabila dilakukan dengan mekanisme atau teknik pemijatan yang benar dan dilakukan oleh orang yang sudah terlatih. Kondisi yang ada dimasyarakat pijat bayi dilakukan oleh dukun pijat yang dilakukan secara tradisional turun temurun. Tujuan penelitian ini untuk mengetahui efektifitas pelatihan pijat bayi terhadap peningkatan pengetahuan dan keterampilan kader balita di Wilayah Kerja Puskesmas Pajangan Bantul. Metode yang digunakan Pre Eksperiment dengan pendekatan One Group Pretest and Posttest. Lokasi penelitian di Puskesmas wilayah Pajangan Bantul dengan Responden kader balita sejumlah 30 orang. Hasil Nilai rata rata pengetahuan responden sebelum diberikan pelatihan 56,25 setelah diberikan pelatihan pijat bayi meningkat menjadi 87,5 . Peningkatan tersebut signifikan yang ditunjukkan dengan one tailed nilai $\mathrm{p}=0,001 \quad(\mathrm{p}<0,05)$. Begitu pula hasil keterampilan responden sebelum diberikan pelatihan tidak tepat dalam memiat atau nol setelah diberikan pelatihan piat bayi menjadi 89,13. Peningkatan tersebut signifikan dengan nilai $\mathrm{p}=0,001 \quad(\mathrm{p}<0,05)$. Kesimpulan pelatihan pijat bayi sangat efektif dalam meningkatkan pengetahuan dan ketrampilan kader kesehatan balita
\end{abstract}

Kata Kunci : Pelatihan, Pijat bayi, Kader balita

\section{ABSTRACT}

Baby massage is a touch therapy that has been existing since ancient times. This massage gives benefits when it is done with a mechanism or correct massage techniques and performed by people who are already trained. Conditions that exist in the community of baby massage is performed by an untrained shaman. Purpose to determine the effectiveness of baby massage training to increase knowledge and skills of cadres toddler in Puskesmas Display Bantul. Methods used Pre Experiment with Pre-experiment design approach one group Pre-test and post-test. The location of the research is in the health center Pajangan Bantul area with a toddler cadre Respondents 30 people. Results The average of respondents' knowledge given training before 56.25 after being given baby massage training increased to 87.5. The significant increase in indicated by the value of $p=0.001$ ( $p<0.05)$. Similarly, the respondent before the results are given training skills "can not" or zero to 89.13 after a baby massage training with a significantly increased $p=$ 0.001 ( $p$ <0.05).. Conclusion baby massage training is very effective in increasing the knowledge and skills of toddler health cadres.

Keywords: training, baby massage, baby Cadre 


\section{PENDAHULUAN}

Pijat bayi merupakan therapi sentuh yang telah ada sejak zaman dulu. Pijat juga merupakan seni perawatan kesehatan dan pengobatan yang telah dipraktikkan sejak berabad-abat silam. Seni pijat dikenal dengan the healing touch karena banyak manfaat kesehatan yang didapat. Pijat merupakan aplikasi tekanan pada jaringan lunak tubuh seperti kulit, otot, tendon dan ligamen. Gerakan dalam pijatan akan memberikan rasa aman, hangat, menyenangkan, nyaman, serta dapat dipergunakan sebagai pereda nyeri dengan menstimulasi produksi endofin dan ensefalin yang alami dan memicu mekanisme gate control (S. Dewi, 2016).

Penelitian terkait dengan pijat bayi telah banyak dilakukan, seperti hasil penelitian yang dilakukan (Hidayanti, 2018), menunjukkan bahwa Pijat bayi yang dilakukan oleh orang tua selama 4 minggu dapat meningkatkan pertumbuhan bayi. Kelompok bayi yang dipijat perubahan berat badan dan panjang badannya lebih tinggi dibandingkan dengan kelompok yang tidak dipijat.
Penelitian serupa juga telah penulis lakukan dengan membandingkan antara Bayi Berat Lahir Rendah (BBLR) yang dilakukan tindakan Kangoro Mather Care (KMC) dan Pijat Bayi dengan BBLR yang dilakukan KMC saja. Hasil penelitian menunjukkan tidakan KMC dan Pijat Bayi lebih efektif dapat meningkatkan berat badan dan panjang badan dibandingkan dengan BBLR yang hanya diberikan KMC saja (Maryati et al., 2015). Intervensi pijat bayi dapat meningkatkan berat badan 5,1 gram perhari dan dapat mengurangi lama tinggal perawatan sebesar 4,5 hari, pijat bayi untuk bayi Prematur terbukti bermanfaat untuk perkembangan anak. Vickers et all (2009).

Penelitian lain yang menghubungkan antara pijat bayi dengan kualitas tidur, menurut Dewi et al., (2014) lama tidur bayi sesudah pemijatan mengalami peningkatan 0,32 jam dibandingkan sebelum pemijatan, frekuensi terbangun bayi dimalam hari sesudah pemijatan mengalami penurunan 0,82 kali dibandingkan sebelum pemijatan, lama terbangun bayi dimalam hari sesudah pemijatan 
mengalami penurunan 2,64 menit dibandingkan sebelum pemijatan.

Satu hal yang sangat menarik pada penelitian pijat bayi adalah mekanisme pemijatan. Mekanisme dasar pijat bayi memang belum banyak diketahui, namun beberapa pakar telah menemukan mekanisme yang dapat menerangkan mekanisme dasar pijat bayi antara lain pengeluaran beta endorphin, aktivitas nervus vagus dan produksi serotonin (S. Dewi, 2016). Pijat bayi bisa dilakukan oleh orang tua (ibu, ayah, nenek atau kakek), tenaga terlatih atau tenaga kesehatan.

Berdasarkan hasil pengkajian kondisi yang ada di masyarakat pijat bayi dilakukan oleh tukang pijat (dukun) bayi yang mana secara umum dukun bayi ini kurang mengetahui prinsip dasar pemijatan sehingga mengakibatkan kejadian yang tidak diinginkan berupa perdarahan intrakranial, hematom di ekstremitas dan terjadi ileus. Dibeberapa rumah sakit telah dilaporkan adanya operasi pada bayi akibat terjadinya perdarahan otak pada bayi akibat dari tehnik pemijatan yang kurang tepat.

Berdasarkan latar belakang tersebut maka perlu dilakukan pelatihan pijat bayi pada kader kesehatan balita. Tahapan pijat bayi yang diberikan dalam pelatihan ini mencakup pemijatan dahi, wajah, dada, perut, tangan, kaki, punggung, diakhiri dengan senam. Teknik pemijatan dilakukan dengan memberikan stimulasi pada bagian bagian tubuh sesuai anatomi fisiologi tubuh. Keuntungan dari dari pijat bayi ini dapat meningkatkan pertumbuhan, perkembangan, dan meningkatkan daya tahan tubuh. Pijat bayi ini bisa dilakukan oleh keluarga atau orang yang terlatih (kader) sehingga diharapkan turut mampu mendukung program ASI eksklusif yang dicanangkan oleh pemerintah teutama mengoptimalkan pertumbuhan perkembangan bayi 1000 hari pertama kehidupan.

Kader kesehatan balita merupakan seorang tenaga sukarela yang direkrut dari, oleh dan untuk masyarakat sebagai perpanjangan tangan tenaga kesehatan yang bertugas membantu kelancaran pelayanan kesehatan. Sebagai perpanjangan tangan tenaga kesehatan maka perlu kiranya Kader Kesehatan mengetahui mekanisme/ langkah langkah dalam pijat bayi agar 
dapat melakukan pijat bayi dengan benar.

Atas dasar itulah maka peneliti melakukan penelitian tentang "Efektifitas Peningkatan

Pengetahuan Dan Keterampilan Pijat Bayi Pada Kader Balita Di Wilayah Kerja Puskesmas Pajangan Bantul”. Tujuan dari penelitian ini untuk mengetahui efektifitas pelatihan pijat bayi terhadap peningkatan pengetahuan dan keterampilan kader balita di Wilayah Kerja Puskesmas Pajangan Bantul.

\section{METODE}

Penelitian ini menggunakan desain Pre eksperimen dengan pendekatan One Group Pretest and Posttest yaitu untuk mengetahui perbedaan atau perubahan pada nilai sebelum dan setelah dilakukan Intervensi pelatihan pijat bayi. Variabel penggangu pendidikan, umur, pekerjaan. Penelitian ini menggunakan rancangan penelitian praeksperimen dengan One group Pretest and posttest design. Rancangan ini tidak ada kelompok pembanding (tidak ada kelompok kontrol) tetapi paling tidak sudah dilakukan observasi pertama (Pretest) yang memungkinkan menguji perubahan perubahan yang terjadi setelah adanya eksperimen (Notoatmodjo, 2012). Pada rancangan ini sebelum diberi intervensi dilakukan Pretest (O1) diikuti intervensi (X) setelah beberapa waktu dilakukan postest (O2) Skema jalannya penelitian adalah sebagai berikut:

$\begin{array}{lll}\text { O1 } & \mathrm{X} & \mathrm{O} 2\end{array}$

Gambar 4.1. Desain penelitian Pre eksperimental Pre and post design

Keterangan

O1: Pengetahuan dan keterampilan kader balita sebelum diberikan perlakuan pelatihan pijat bayi.

O2: Pengetahuan dan keterampilan kader balita setelah diberikan perlakuan pelatihan pijat bayi.

X : Pelatihan pijat bayi pada kader balita di Wilayah Kerja Puskesmas Pajangan Bantul.

Kegiatan yang dilakukan untuk mencapai tujuan penelitian berupa pelatihan pijat bayi yang dilaksanakan selama 2 hari dengan waktu kurang lebih 8 jam per hari (08.00 - 16.00).

Tahap tahap piat bayi meliputi:

1. Persiapan: alat, tempat, petugas 
2. Preinteraksi Memulai pemijatan dengan membelai wajah dan kepala bayi sambil mengajaknya bicara

3. Tahap kerja : mulai dari Menyeterika dahi, memijat wajah, dada. Perut, tangan, kaki, punggung, senam

4. Tahap terminasi dan dokumentasi Populasi dalam penelitian adalah kader posyandu balita Desa Sendang sari Pajangan Bantul sebanyak 117 orang kader. Pengambilan sample dilakukan secara random sebanyak 30 orang kader. Pelatihan pijat bayi ini dilaksanakan secara terstruktur meliputi kegiatan Pretes dan pos tes, ceramah tanya jawab dan demonstrasi. Adapun langkah langkah kegiatn pelatihan adalah sebagai berikut:

1. Pada hari 1

Sebelum kegiatan pelatihan dilakukan, Responden atau peserta pelatihan diberikan Pretest dengan instrumen berupa soal yang berkaitan dengan pijat bayi yang sudah disiapkan. Hal ini dilakukan untuk mengukur kemampuan awal responsden sebelum diberikan tindakan. Setelah diberikan Pretest diberikan materi pelatihan berupa: tumbuh kembang bayi dan balita dan pijat bayi, demonstrasi praktik pijat bayi.

2. Pada hari 2

Peserta pelatihan melakukan praktik pijat bayi menggunakan alat phantom, matras, selimut bayi dan minyak telon. Setiap peserta melakukan pijat bayi secara bergantian sesuai dengan langkah langkah pijat bayi yang ada di instrumen berupa lembar observasi atau kuesioner pijat bayi. Setelah semua peserta mendemonstrasikan pijat bayi selanjutnya dilakukan penilaian ketrampilan pijat bayi oleh peneliti. Sebagai akhir kegiatan pelatihan dilakukan post test.

Lokasi penelitian ini dilakukan di Wilayah Kerja Puskesmas Pajangan Bantul. Pelaksanaan pelatihan dilakukan di Puskesmas Pajangan Bantul. Responden dalam penelitian ini adalah Kader Balita di Posyandu wilayah kerja Puskesmas Pajangan Bantul sebanyak 30 orang. Instrumen yang digunakan untuk penelitian berupa:

1. Penilaian pengetahuan diukur menggunakan soal tentang pijat 
bayi sebelum (Pre test) dan setelah (post test) dilakukan intevensi (pelatihan) diukur berdasarkan jumlah jawaban benar, nilai 1 jika jawaban benar dan nilai 0 jika jawaban salah.

2. Pengukuran keterampilan, alat bantu yang digunakan untuk pengumpulan data kuantitatif berupa lembar observasi atau kuesioner untuk penilaian keterampilan berupa langkah langkah prosedur pijat bayi. Data disusun secara terstruktur berdasarkan variabel penelitian. Alat tersebut digunakan untuk mengambil data primer. Pelatih piat bayi dilakukan oleh peneliti sendiri yang sebelumnya sudah mendapatkan pelatihan dan sudah tersertifikasi.

\section{HASIL DAN PEMBAHASAN}

\section{Gambaran Umum Lokasi Penelitian}

Puskesmas Pajangan. Pajangan beralamat di Jl. Benyo, Sendangsari, Pajangan, Bantul, DIY memiliki luas tanah $+1600 \mathrm{~m} 2, \quad$ terletak di sebelah timur kantor Kecamatan Pajangan. Jarak antara puskesmas dengan kecamatan $+3 \mathrm{~km}$, jarak puskesmas - kabupaten $+7 \mathrm{~km}$. Jarak dengan Kota Yogyakarta $+20 \mathrm{~km}$. Sedangkan Batas Wilayah Kecamatan pajangan, Utara Kecamatan : Desa Bangunjiwo Kasihan dan Desa Argodadi Sedayu. Timur Kecamatan: Desa Ringinharjo, Kec. Bantul. Selatan Kecamatan : Desa Wijirejo, Kec. Pandak, Barat Kecamatan : Sungai Progo.

Puskesmas Pajangan telah terakreditasi paripurna dengan izin operasional No0007/DP/210/XI/2015. Jenis pelayanan kesehatan di Puskesmas Pajangan terdapat dua kategori meliputi UKP (Usaha Kesehatan Perorangan) dan UKM (Usaha Kesehatan Masyarakat). UKP terbagi menjadi layanan Rawat Jalan dengan unit pelayanan poli Umum, poli gigi, promosi kesehatan, KIA, laboratorium, fisioterapi, dan farmasi, sedangkan layanan Rawat Inap dengan unit pelayanan rawat umum, dan persalinan. Pada pelayanan UKM melaksanakan 6 perogram esensial atau pokok yaitu KIA/KB, gizi, kesehatan lingkungan, P2 (Pemberantasan Penyakit), Promkes, perawatan kesehatan masyarakat. Adapun program pengembangan puskesmas yaitu upaya kesehatan jiwa, upaya kesehatan lansia, dan 
upaya kesehatan gizi masyarakat.

Penelitian ini dilakukan sebagai upaya meningkatkan pelayanan promosi kesehatan dan fisiotherapi.

(https://puskesmas.bantulkab.go.i

d/pajangan).

\section{Distribusi Frekuensi Karakteristik}

\section{Subjek Penelitian}

Analisis Univariabel dibuat dengan tujuan untuk menggambarkan karakteristik dari subjek penelitian sehingga kumpulan data tersebut menjadi informasi yang berguna. Jumlah responden dalam penelitian ini sebanyak 30 responden dengan karakteristik responden disajikan dalam tabel 5.1.

Tabel 5.1. Distribusi Frekuensi Karakteristik Subjek Penelitian Berdasarkan Variabel Penelitian

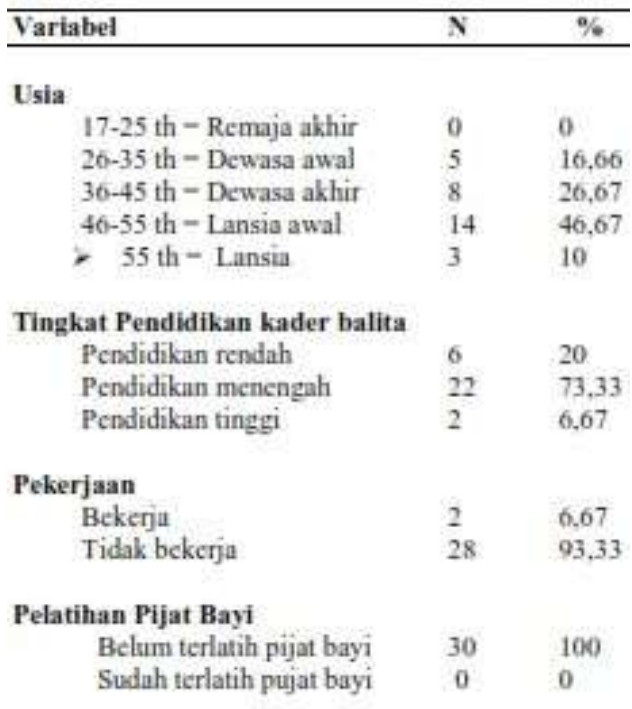

Sumber : Analisis data primer 2019

Berdasarkan tabel diatas menunjukkan bahwa sebagian besar usia kader kesehatan balita termasuk pada kelompok usia lansia awal sebanyak $46,67 \%$ dan tidak ada kader kesehatan balita yang berada pada kelompok usia remaja akhir.

Jika dilihat dari tingkat pendidikan kader kesehatan balita sebagian besar berada pada kelompok pendidikan menengah (SMP dan SMA) sebanyak $73,33 \%$ dan hanya sebagian kecil yang berada pada kelompok Pendidikan Tinggi sebanyak 6,67\%.

Apabila dilihat dari jenis pekerjaan maka sebagian besar kaderkesehatan balita tidak bekerja sebanyak 93,33\% sedangkan kader kesehatan balita yang bekerja sebanyak 6,67\%. Selanjutnya jika dilihat dari pengalaman kader 
kesehatan balita dengan menanyakan apakah kader sudah pernah mendapatkan pelatihan pijat bayi ?, maka semua kader kesehatan balita belum pernah mendapatkan pelatihan pijat bayi.

Jadi berdasarkan data diatas maka dapat disimpulkan bahwa kader kesehatan balita di wilayah kerja Puskesmas Pajangan sebagian besar berusia lansia awal, dengan tingkat pendidikan sebagian besar SMP atau SMA, tidak bekerja serta semua kader kesehatan balita belum pernah mendapatkan pelatihan pijat bayi.

Tabel 5.2 Tingkat Pengetahuan dan Keterampilan Praktik Pijat Bayi sebelum diberikan pelatihan pijat bayi dengan setelah diberikan pelatihan pijat bayi pada kader balita di wilayah kerja Puskesmas Pajangan Bantul.

\begin{tabular}{cccc}
\hline & \multicolumn{1}{c}{$\begin{array}{c}\text { Sebelum } \\
\text { pelatihan }\end{array}$} & $\begin{array}{c}\text { Setelah } \\
\text { Pelatihan }\end{array}$ \\
\cline { 2 - 3 } & $f$ & $\%$ & $\begin{array}{c}\mathbf{f} \\
\%\end{array}$ \\
\hline Tingkat & & & \\
pcngetahuan & 1 & 3,33 & 22 \\
pijat bayi & 17 & 73,34 \\
Baik & 56,67 & 7 \\
Cukup & 12 & 40 & 23,33 \\
Kurang & & & 1 \\
Keterampilan & & & 3,33 \\
Praktik pijat & 0 & 0 & 29 \\
bayi & 0 & 0 & 96,67 \\
Baik & 0 & 0 & 1 \\
Cukup & & & 3,33 \\
Kurang & & & 0 \\
\hline
\end{tabular}

Berdasarkan tabel 5.2 menunjukkan bahwa tingkat pengetahuan kader kesehatan balita tentang pijat bayi sebelum diberikan pelatihan sebagian besar cukup sebanyak $56,67 \%$ dan hanya sebagian kecil dengan tingkat pengetahuan baik. Setelah dilakukan pelatihan sebagian besar tingkat pengetahuan baik sebanyak 73,34\% dan hanya sebagian kecil dengan keterampilan pijat bayi cukup sebanyak 3,33\%. Jika dilihat dari keterampilan praktik pijat bayi, semua kader kesehatan balita belum pernah mendapatkan pelatihan tentang pijat bayi sehingga nilainya 0 , namun setelah diberikan pelatihan sebagian besar keterampilan tentang pijat bayi baik sebanyak 96,67\% dan hanya sebagian kecil dengan keterampilan pijat bayi cukup sebanyak 3,33\%.

\section{Analisis Bivarat}

Analisis bivariat dilakukan untuk mengidentifikasi ada tidaknya perbedaan sebelum diberikan pelatihan dengan setelah diberikan pelatihan pijat bayi. Uji statistik yang digunakan adalah Wilcoxon Signed Rank Tes, sedangkan uji normalitas yang digunakan adalah uji Shapiro wilk. Berdasarkan hasil uji normalitas diperoleh data seperti pada tabel 5.3. 
Tabel 5.3 Distribusi Variabel

Pengetahuan dan Keterampilan

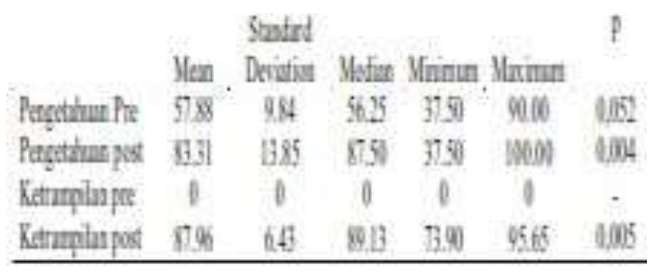

Data tabel 5.3 menunjukkan uji normalitas pengetahuan Pretest diperolah nilai $p>0,05$ yang berarti data berdistribusi normal, sedangkan keterampilan Pretest tidak bisa diukur karena secara keseluruhan skor nol, namun skor pengetahuan postest dan ketrampilan postest diperoleh $\mathrm{p}<0,05$ yaitu data tidak berdistribusi normal. Sehingga analisis menggunakan non parametric. Selanjutnya untuk mengetahui perbedaan pengetahuan dan keterampilan pijat bayi sebelum diberikan pelatihan dengan setelah diberikan pelatihan pijat bayi dapat dilihat pada tabel 5.4.

Tabel 5.4 Perbedaan pengetahuan dan keterampilan pijat bayi antara sebelum diberikan pelatihan pijat bayi dengan setelah diberikan pelatihan pijat bayi pada kader balita di wilayah kerja Puskesmas Pajangan Bantul.

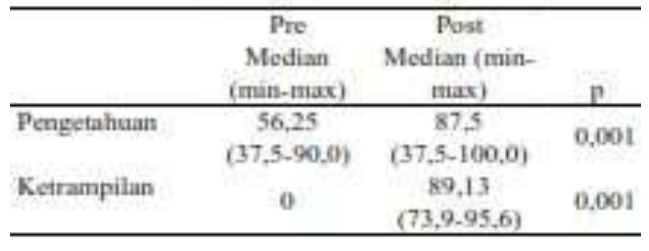

Data tabel 5.4 menunjukkan bahwa Median pengetahuan responden sebelum diberikan pelatihan 56,25 meningkat menjadi 87,5 setelah diberikan pelatihan pijat bayi. Peningkatan tersebut signifikan yang ditunjukkan oleh nilai $\mathrm{p}=0,001$ $(\mathrm{p}<0,05)$. Begitu pula hasil keterampilan responden sebelum diberikan pelatihan tidak bisa atau nol menjadi 89,13 setelah pelatihan pijat bayi dengan peningkatan yang bermakna $\mathrm{p}=0,001 \quad(\mathrm{p}<0,05)$. Artinya pelatihan pijat bayi sangat efektif dalam meningkatkan pengetahuan dan ketrampilan kader kesehatan balita.

Uji statistik untuk mengetahui hubungan antara variabel luar dengan pengetahuan pijat bayi pada kader kesehatan balita menggunakan uji Korelasi Spearman sebagaimana disajikan dalam tabel 5.5.

Tabel 5.5 Hubungan variabel luar dengan pengetahuan

\begin{tabular}{lcc}
\hline Variabel & $\mathrm{r}$ & $\mathrm{p}$ \\
\hline Usia & $-0,148$ & 0,435 \\
Pendidikan & 0,366 & 0,047 \\
Pekerjaan & $-0,051$ & 0,788 \\
\hline
\end{tabular}


Data diatas menunjukkan Tidak ada hubungan yang bermakna usia dan pekerjaan terhadap pengetahuan $(\mathrm{p}>0,05)$. Sedangkan pendidikan memiliki hubungan yang signifikan dengan pengetahuan nilai $\mathrm{p}=0,047$ $(\mathrm{p}<0,05)$. Koefisien korelasi $\mathrm{r}=0,366$ (positif) yang berarti semakin tinggi pendidikan responden semakin tinggi pula pengetahuannya dengan keeratan hubungan kategori lemah yaitu berada pada interval 0,2-0,399.

\section{HASIL DAN PEMBAHASAN}

\section{Usia}

Penelitian ini dilakukan di wilayah kerja Puskesmas Pajangan Bantul dengan responden Kader Kesehatan balita berjumlah 30 orang. Jika dilihat dari tingkat usia sebagian besar kader kesehatan balita termasuk lansia awal usia 46 - 55 tahun sebanyak 46,67\%. Meskipun usia lansia namun hal ini bukan menjadi halangan untuk belajar hal ini dibuktikan dengan hasil Pre dan post test tingkat pengetahuan menunjukkan bahwa Median pengetahuan responden sebelum diberikan pelatihan 56,25 meningkat menjadi 87,5 setelah diberikan pelatihan pijat bayi. Peningkatan tersebut signifikan yang ditunjukkan oleh nilai $\mathrm{p}=0,001(\mathrm{p}<0,05)$.

Mengingat pendidikan kesehatan (pelatihan) merupakan proses yang dinamis dan interaktif maka penting bagi peneliti mempertimabangkan psoes tumbuh kembang kader. Peswrta palatihan adalah kader kesehatan balita yang usianya sebagian besar awal lansia maka pendekatan yang dilakukan adalah dengan membuat ukuran tulisan dengan lebih besar, volume suara lebih tegas dan tidak melengking, melakukan brain storming, diskusi, serta memperbanyak praktik meskipun beberapa materi perlu diulang ulang hingga kader bisa memahami dan mempraktikkan.

Inilah pentingnya peneliti melakukan pengkajian mengenai kemampuan fungsi fisiologis dan psikologis sebelum memberikan pelatihan. Proses penuaan akan mempengaruhi kemampuan pembelajaran, perubahan kognisi akibat proses aging akan mempengaruhi fungsi mental, menurunnya daya ingat jangka pendek, penurunan kemampuan berfikir abstrak, penurunan kemampuan konsentrasi dan penurunan kemampuan untuk bereaksi. 
Strategi pembelajaran yang dapat digunakan pada kondisi perubahan kognisi adalah dengan cara memberikan materi dengan sedikit sedikit, tempo lambat, repetisi informasi yang sering menggunakan media seperti audiovisual, tertulis dan sesi praktik atau demonstrasi yang berulang. Lingkungan pemebajaran pun harus mendukung agar tidak mengganggu konsentrasi klien.

Perubahan sensori akibat proses aging dapat mempengaruhi proses pembelajaran baik langung maupun tidak. Strategi pembelajaran yang dapat digunakan pada kondisi perubahan sensori adalah membuat ukuran tulisan dengan lebih besar, volume suara tegas dan tidak melengking, dilakukan dengan beradapan (Niman, 2017).

\section{Tingkat Pendidikan}

Apabila dilihat dari tingkat pendidikan sebagian besar pendidikan kader kesehatan balita menengah (SMP dan SMA) sebanyak 73,33\%. Seseorang dengan tingkat pendidkan menengah bisa menerima informasi dengan baik, hal ini dibuktikan dengan hasil pelatihan terdapat peningkatan pengetahuan yang signifikan yang ditunjukkan oleh nilai $\mathrm{p}=0,001$ $(\mathrm{p}<0,05)$.

Sebagai salah satu faktor yang mempengaruhi pengetahuan seseorang adalah tingkat pendidikan artinya semakin tinggi tingkat pendidikan semakin luas tingkat pengetahuannya, namun bukan berarti seseorang dengan pendidikan rendah mempunyai pengetahuan yang rendah pula. Hal ini disebabkan adanya kemajuan teknologi yang semakin pesat, seseorang bisa memperoleh pengalaman dan pengetahuan dari media sosial yang tidak terbatas.

Demikian pula dengan pendidikan yang terkait dengan kesehatan, seseorang bisa memperoleh pendidikan kesehatan dari berbagai media sosial. Kader kesehatan balita bisa mengetahui tentang pijat bayi melalui berbagai media komunikasi sehingga ketika akan diberikan pelatihan pengetahuan kader berada pada tingkatan cukup sebanyak 56,67\%, setelah diberikan pelatihan meningkat menjadi baik sebanyak $73,34 \%$ dan hanya $3,33 \%$ dengan pengetahuan kurang.

Hal ini membuktikan bahwa makin tinggi pendidikan seseorang semakin 
mudah pula mereka menerima informasi, dan pada akhirnya makin banyak pula pengetahuan yang dimilikinya. Sebaliknya, jika seseorang tingkat pendidikannya rendah, akan menghambat perkembangan sikap seseorang terhadap penerimaan, informasi dan nilai- nilai yang baru diperkenalkan (Arikunto, 2010).

\section{Pekerjaan}

Berdasarkan karakteristik pekerjaan dibagi menjadi bekerja dan tidak bekerja. Sebagian besar kader kesehatan balita tidak bekerja sebanyak 93,33\%, hal ini menunjukkan kader kesehatan balita cukup waktu untuk memberikan pelayanan di posyandu serta mempunyai waktu yang cukup untuk mengikuti pelatihan pijat bayi dan selanjutnya bisa mensosialisasikan pijat bayi ke masyarakat di wilayah kerjanya.

Secara tidak langsung pekerjaan turut andil dalam mempengaruhi tingkat pengetahuan seseorang, hal ini dikarenakan pekerjaan berhubungan erat dengan faktor interaksi social dan kebudayaan, sedangkan interaksi sosial dan budaya berhubungan erat dengan proses pertukaran informasi. Dan hal ini tentunya akan mempengaruhi tingkat pengetahuan seseorang (Notoatmodjo, 2012).

\section{Pelatihan Pijat bayi}

Semua kader belum pernah mendapatkan pelatihan pijat bayi sehingga pada saat diberikan materi pelatihan teori maupun praktik sangat antusias dan rasa keingin tahuan yang besar. Hal ini dibuktikan pada saat pelatihan semua kader yang diundang hadir dan mengikuti proses pelatihan dari awal sampai akhir. Sebagian besar kader juga aktif bertanya dan melakukan praktik pijat bayi dengan semangat.

\section{Tingkat pengetahuan}

Hasil penelitian ini menunjukkan tingkat pengetahuan kader kesehatan balita tentang pijat bayi sebelum diberikan pelatihan sebagian besar cukup sebanyak $56,67 \%$ dan hanya sebagian kecil dengan tingkat pengetahuan baik. Setelah dilakukan pelatihan sebagian besar tingkat pengetahuan baik sebanyak 73,34\% dan hanya sebagian kecil dengan 
tingkat pengetahuan kurang sebanyak $3,33 \%$.

Uji statistik yang digunakan adalah Wilcoxon Signed Rank Tes. Hasil penelitian ini menunjukkan bahwa median pengetahuan responden sebelum diberikan pelatihan 56,25 , setelah diberikan pelatihan pijat bayi meningkat menjadi 87,5. Peningkatan tersebut signifikan yang ditunjukkan oleh nilai $\mathrm{p}=0,001 \quad(\mathrm{p}<0,05)$. Hal ini sesuai dengan penelitian pijat bayi yang dilakukan oleh Vitrianingsih dkk, (2018) dengan responden ibu yang mempunyai anak usia 0-24 bulan berdasarkan uji paired t-test antara pengetahuan sebelum dan setelah dilakukan pelatihan didapatkan p-value $0,004<0,05$ artinya kegiatan pelatihan efektif meningkatkan pengetahuan ibu. Sedangkan untuk sikap sebelum dan setelah dilakukan pelatihan didapatkan p-value

$0,001<0,05$ sehingga dapat diartikan pelatihan efektif merubah sikap ibu dari negatif menjadi positif. Pelatihan pijat bayi efektif meningkatkan pengetahuan dan sikap ibu tentang pijat bayi .

Penelitian yang hampir sama juga dilakukan oleh Prananingrum et al., (2017), responden dalam penelitian ini adalah Kader Posyandu balita berjumlah 38 orang diperoleh hasil pendidikan dan pelatihan pijat bayi meningkatkan pengetahuan kader posyandu balita.

\section{Keterampilan Pijat bayi}

Semua kader kesehatan balita belum pernah mendapatkan pelatihan tentang pijat bayi sehingga nilainya 0 , namun setelah diberikan pelatihan sebagian besar keterampilan tentang pijat bayi baik sebanyak $96,67 \%$ dan hanya sebagian kecil dengan keterampilan pijat bayi cukup sebanyak 3,33\%.

Hasil uji statistik menunjukkan keterampilan responden sebelum diberikan pelatihan tidak bisa atau nol setelah diberikan pelatihan pijat bayi menjadi 96,67\% dengan peningkatan yang bermakna $p=0,001$ $(\mathrm{p}<0,05)$. Artinya pelatihan pijat bayi sangat efektif dalam meningkatkan pengetahuan dan ketrampilan kader kesehatan balita. Penelitian serupa dilakukan oleh Marni, (2018), dengan responden Kader Posyandu Balita berjumlah 31 orang berdasarkan uji Wilcoxon diperoleh nilai P: 0,000 yang berarti 
ada perbedaan yang bermakna dari nilai keterampilan pada saat Pretest dan posttest. Sedangkan penelitian yang dilakukan oleh Wati \& Renityas, (2014) dengan responden Ibu yang memiliki bayi usia 0-12 bulan di BPS Kirana, Desa Jatinom, analisis menggunakan wilcoxon, dengan tingkat signifikan $\leq 0,05$. Hasil penelitian menunjukkan bahwa pendidikan kesehatan pijat bayi mempengaruhi keterampilan pijat bayi, dengan uji wilcoxon diperoleh p-value 0,000 .

Butsainatul dkk (2015) melakukan penelitian tentang perilaku ibu dalam melakukan pijat bayi, responden dari penelitian ini adalah ibu balita berjumlah 21 orang, dengan uji Wilcoxon Rank Test diperoleh hasil $\rho=0,000 \quad(\rho<$ $0,05)$, artinya ada pengaruh pendidikan kesehatan tentang pijat bayi terhadap perilaku ibu dalam memijat bayi secara mandiri di Kelurahan Girimargo Sragen Baroo'ah et al., (2015).

\section{SIMPULAN}

Berdasarkan hasil penelitian maka dapat disimpulkan :
1. Pelatihan pijat bayi efektif meningkatkan pengetahuan dan keterampilan kader balita di Wilayah Kerja Puskesmas Pajangan Bantul

2. Sebelum diberikan pelatihan pijat tingkat pengetahuan kader balita bayi rata rata cukup, sedangkan keterampilan semua kader balita kurang

3. Setelah diberikan pelatihan pijat tingkat pengetahuan dan keterampilan kader balita bayi rata rata baik.

4. Ada perbedaan yang signifikan pada tingkat pengetahuan dan keterampilan kader balita antara ssebelum dan setelah diberikan pelatihan pijat bayi.

5. Jika dilihat dari hubungan antara karakteristik kader balita dengan pengetahuan maka tidak ada hubungan yang bermakna antara usia dan pekerjaan dengan tingkat pengetahuan, ada hubungan yang bermakna antara pendidikan dengan tingkat pengetahuan. semakin tinggi pendidikan semakin tinggi pula tingkat pengetahuannya. 
SARAN

1. Bagi kader balita membiasakan keterampilan dengan melakukan pemijatan balita pada saat pelayanan di Posyandu,

2. Bagi kader balita hendaknya mensosialisasikan sekaligus mengajarkan tehnik pijat bayi ini kepada semua ibu yang mempunyai balita

3. Bagi pengelola Pijat bayi bisa digunakan sebagai tambahan jenis pelayanan di Posyandu balita diwilayah Puskesmas Pajangan Bantul sehingga diharapkan dapat meningkatkan strata Posyandu.

\section{DAFTAR PUSTAKA}

Arikunto. (2010). Prosedur Penelitian: Suatu Pendekatan Praktek. Rineka Cipta.

Baroo'ah, B., Arifah, S., \& Yuniartika S, W. (2015). Pengaruh pendidikan kesehatan tentang pijat bayi terhadap perilaku ibu dalam memijat bayi secara mandiri di kelurahan girimargo sragen. 11.

Dewi, S. (2016). Pijat dan Asupan Gizi Tepat untuk Melejitkan
Tumbuh Kembang Anak. Pustaka Baru Press.

Dewi, U., Aminin, F., \& Gunnara, H. (2014). The Effects of Massage on the Quality of Sleeping in Babies 3-4 Months Old at Gelatik and Nuri IHCs of Tanjung Unggat Village of Tanjungpinang in 2014. Jurnal Ners Dan Kebidanan (Journal of Ners and Midwifery), 1(3), 230-235. https://doi.org/10.26699/jnk.v1i3. art.p230-235

Hidayanti, D. (2018). the Effect of Infant Massage To the Newborn' $S$ Growth At Community. 4(4), 197-209.

MARNI, M. (2018). Keterampilan Pijat Bayi Pada Kader Posyandu Sebelum Dan Setelah Pelatihan. Profesi

(Profesional Islam): Media

Publikasi Penelitian, 16

(1),22.https://doi.org/10.26576/ profesi. 285

Maryati, S., Kesehatan, A., \& Husada, K. (2015). Kangaroo Mother Care Dan Pijat Bayi Efektif Meningkatkan Berat.3(3), 198-205. 
Niman. (2017). Promosi dan

pendidikan kesehatan. Trans

Info Media.

Notoatmodjo, S. (2012). Metodologi

Penelitian Kesehatan. Rineka

Cipta.

Prananingrum, R., Untari, I., Pertiwi,

D., \& Kusudaryati, D. (2017).

Peningkatan Pengetahuan dan

Ketrampilan Kader Posyandu

Balita Melalui Praktek Pijat

Bayi Menuju Balita Sehat. 249-

254.

Wati, A. M., \& Renityas, N. N. (2014). The Effect of Health

Education to Baby Massage Skill.

Jurnal Ners Dan Kebidanan

(Journal of Ners and Midwifery),

1(1), 052-056.

https://doi.org/10.26699/jnk.v1i1.

art.p052-056 